\title{
SOCIAL, CULTURAL AND ECONOMIC VALUE OF BUSINESS EVENTS - DESIGNING CONTENT VERSUS CREATIVITY EXPERIENCES
}

\section{KRZYSZTOF CELUCH}

Vistula School of Hospitality

e-mail:k.celuch@vistula.edu.pl

\section{\begin{tabular}{l|l} 
JEL CODES & L8, R1, L83
\end{tabular}}

KEYWORDS meetings, events, organizations, creativity, culture, conference

ABSTRACT To encourage stronger discussions amongst various interdisciplinary fields and to synthesize the diversity of business events into a coherent framework, which advances understanding in the unpredictable world of association meetings and corporate events, we need to focus on money. The main goal of writing this article was to elaborate on the value of events in different perspectives. Especially those linked to the second most important issue after human interactions, which is the business impact of events.

\section{Introduction}

The meetings industry influences the economic development of countries; it also helps increase the employment rate in regions where, so far, the development of broadly understood tourism has proved problematic. It is recommended not only to consider its possibilities but also to intensify the activities connected with its promotion, management and organization. Managing the meetings industry (Events Industry Council, 2015) as a new and innovative phenomenon discloses various 
gaps in its systemic growth. Qualitative and quantitative analyses of the studied meetings form a basis for regional growth and a determinant of directions in which this industry can develop. Newly created congress centers, companies providing services to business customers and staff education facilities form a basis for the ongoing development of this industry. "When we have a convention in town, it is as if an airplane flew overhead dropping dollar bills on everyone".

This statement by a mayor of a US city proves the economic significance of organizing such meetings as conventions, conferences or peaks for the host-city. It is quoted by many market commentators and analysts (Davidson, Cope, 2001, pp. 70-76). Indeed: figures contained in the reports drafted on the basis of statistics (e.g. by the ICCA - International Congress and Convention Association, the UIA - Union of International Associations) indicate that the so-called congress tourist, i.e. a convention or conference participant, spends a lot more money at the event location than an individual tourist, notwithstanding the fact that his participation in the meeting had already been paid (average expenses per one conference participant acc. to ICCA amount to USD 736) (ICCA, 2017) and irrespective of whether such a participant had been invited by an association they are a member of, a corporation or a public institution. It seems, therefore, that conference and congress business is the most profitable "slice" of the meetings industry cake.

Conferences are a vital economic benefactor for both local and national economies. Investment in conference facilities and infrastructure can bring substantial returns through the expenditure of organizers and delegates, with both direct and indirect benefits for the destinations in which conferences are held. While statistics and intelligence about the industry are not yet as well developed as those working in the industry would wish to see, sufficient information and research findings do exist to enable estimates of its value, and potential to be made with confidence (Rogers, 2003).

If we are talking about business events the most crucial aspect of it are people. However human connections and interactions these days are under a lot of pressure. Not only do we not have time to speak to each other but also very often we are running away from direct conversations. Fortunately, there is a meeting industry where different things happen and still people's choices are the most important.

Tourists spend their money on a wide variety of goods and services. They purchase accommodation, food and beverage, communications, entertainment services, goods from retail outlets and tour/travel services, to name just a few. This money may be seen as an injection of demand into the host economy: that is, demand which would otherwise not be present. However, the value of tourist expenditure represents only a partial picture of the economic impact. The full assessment of economic impact must take into account other aspects, including the following:

- indirect and induced effects,

- leakages of expenditure out of the local economy,

- displacement and opportunity costs. (Cooper, Fletcher, Gilbert, Fyall, Wanhill, 1993; Rogers, 2003). 


\section{Economic value of husiness events}

Speaking about economic value of business events, it is significant to mention the document by the World Tourism Organization on the meetings industry, according to which "the Meetings Industry has three main components that will be examined here: meetings and conferences, exhibitions and incentives" (UNWTO, 2006).

However, having analyzed all the aforementioned attempts at formulating a definition, one might try and define the meetings industry as a sector of economy connected with organizing and promoting meetings and managing meetings, including congresses, conferences, trade shows, corporate events, and incentive travel (Celuch, 2010b).

Such a definition is not only a broader presentation of the phenomenon but also indicates that tourism is only one part of it. The meetings industry, as an increasingly important branch of the economy, is using other various forms of economic activity, from hospitality and hotel management and catering through marketing and advertising to management and finance. From this perspective, it is an interdisciplinary field which requires individual treatment and separate analysis. Its nature has been shown above in the light of the main goals of organizing meetings but also through goals including content (congresses and conferences), product (events, event marketing), or incentive travel and the tourist aspect. Speaking about the meetings industry and impact, it is worth mentioning that different bodies have an influence on it. That is why it is worth mentioning the stakeholders and their role. Discussing the market systematization, the author proposes a model of cooperation between the participants of the meetings industry based on meeting goals. When describing the needs connected with the meeting goal, the customer determines its category in accordance with the "content, product, motivation" division and only on that basis do they select the organizer, venue and subcontractors specializing in the organization of the given meeting type (fig. 1).

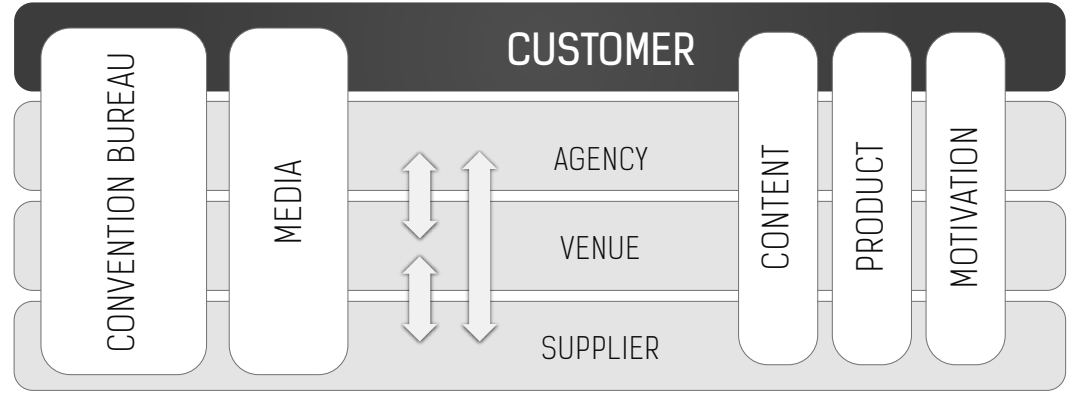

Figure 1. Model of cooperation between the participants of the meetings industry in division by goals Source: Celuch (2010b), p. 73.

The role of the customer (and, in the age of the meetings industry's development globally and in the light of their increasingly stronger position, their business obligation) is to take informed decisions on the organization and management of meetings in the scope of the customer's strategy, 
communication and marketing activity. The model, assuming the division of the meetings industry (and identification of market participants) by content, product and motivation, will help systematize and order actions connected with the growth of this branch of the economy. As follows from the above discussion aimed at determining the essence of the meetings industry, the starting point in the context of efficiency and profitability of using respective tools is always a precise definition of a goal. Therefore, it is necessary to analyze the meetings industry from the point of view of the final (or key) goal and the effect of its products. The goals of each organized meeting might include information and presentation, promotion, motivation, team-building, sales support, exchange of opinions, new experiences, etc. Depending on which of these is perceived as the main goal, we can treat the meetings industry as a set of tools and activities focused on content, product and motivation.

The author presents his suggestions according to this very division. The meetings industry is not perceived as a branch of economy, which impedes its academic classification. This is connected, among other things, with education; a question arises as to whether specialists in meetings organizations should be educated in tourism and recreation or management. It is also important to discuss the aspect of studies and research projects. At present, there are various studies (and on various scales) pending, connected with destination management, region management, and the qualitative and quantitative analysis of meetings and events. It should be noted, however, that the meetings industry is not analyzed within the scope of the satellite account system.

The national account system is a set of tables describing phenomena occurring in the economy. The SNA 1993 account system is an international model on which all national accounts in various countries are made; it is recommended both by the UN and the European Union. It is on this model that the European System of National Accounts used. The national accounts are prepared according to two formulas:

- by institutional sectors,

- by operation types (GUS, 2002).

Tourism is just as fragmented as the meetings industry, but it has its satellite account maintained on the national level. Furthermore, there is a satellite account maintained for the cultural sector which is also a very interdisciplinary phenomenon. The meetings industry must be perceived as a research field, if only through having a satellite account established.

Since tourism cannot be identified with any institutional sector, type of activity or product, the only way to estimate its influence on the economy is to create a satellite account. The goal of the tourism satellite account (TSA) is to obtain information on economic activity connected with tourism and ensure its comparability with the results of other economic branches (GUS, 2002).

The concepts of resident and non-resident are crucial in classifying a given institutional entity to the "foreign" sector. The criterion for recognizing a given entity as resident is for that entity to conclude transactions within the economic area of a given country for at least one year. 
Regional cooperation and development are the key activities benefiting the meetings industry. Establishing consortia and highlighting the strength of their operations through the synergies between respective entities is the main task. It is a common trend that global business events more often look for cooperation with regions with dedicated industries. That means meetings are strictly linked to the content or subject interest. However, business guests, or in some regions still named as tourists, have a big influence on local and regional markets.

The indirect effect will not involve all of the moneys spent by tourists during the direct effect, since some of that money will leak out of circulation through imports, savings and taxation. Finally, during the direct and indirect rounds of expenditure, income will accrue to profit, rent and interest. This addition to the local income will, in part, be represent in the local economy on goods and services, and this will generate yet further rounds of economic activity. It is only when all three levels of impact (direct plus indirect plus induced) are estimated that the full positive economic impact of tourism expenditure is fully assessed (Rogers, 2003).

To show the full picture of business events we have to remember about negative aspects as well. Cooper et al. (1993) also make reference to certain "negative economic impacts" of tourist expenditure. These include opportunity costs and displacement effects. Opportunity costs refer to the use of resources, such as labor and capital, for the benefit of one industry rather than another. Decisions to invest limited capital resources in tourism infrastructure, for example, will have negative impact on other industries that failed to attract that investment:

Where tourism development substitutes one form of expenditure and economic activity for another, this is known as the displacement effect. Displacement can take place when tourism development is undertaken at the expanse of another industry and is generally referred to as the opportunity cost of the development. However, it is more commonly referred to when a new tourism project is seen to take away custom from an existing facility. For instance, if a destination finds that its all-inclusive hotels are running at high occupancy levels and returning a reasonable yield on investment, the construction of and additional all-inclusive hotel may simply reduce the occupancy levels of the existing establishments, and the destination may find that its overall tourism activity has not increased by as much as the new business from the development. This is displacement (Rogers, 2003).

However, speaking about negative aspects, we need to remember that more and more destinations are considered as meetings "friendly". This proves that economic impact on the destination is much stronger than the negative impressions. "Calculations of the economic impact of conference business must take into account a number of negative economic impacts, such as opportunity costs and displacement costs, as well as the cascade of positive benefits, in order to arrive at an accurate assessment of net beneficial effects" (Rogers, 2003).

According to one of the research, many sections of local community's benefit from business events:

National surveys and local studies confirm that conference tourism occupies one of the top places at the high-yield end of the tourism spectrum. It provides substantial economic benefits 
for those countries that have embraced it vigorously and invested in the necessary infrastructure to attract and retain conference business. It sustains jobs that are all-year-round and brings income through delegate expenditure, which benefits many sections of local communities (Rogers, 2003).

Economy or travel economy is another expression which is used in the literature. Not only is it a different point of view but also a very popular approach.

Meetings and conventions (MICE) visitation is often considered an important element of the travel economy, and destinations target such activities to encourage their growth. It has hitherto been difficult to measure the economic significance of such activity at any spatial scale. Latterly, the development and codification of tourism satellite account (TSA) approaches to the economic measurement of tourism offers an opportunity to develop a parallel approach to understanding the MICE economy. This paper presents an estimate of the direct economic impact of MICE activity in the UK in 2011, following TSA approaches. The potential to extend the core Meeting Satellite Account, to estimate indirect economic impact and sub-national economic impacts, is also assessed (Jones, Li, 2015).

Here we seek to provide two key contributions. Firstly, to establish whether the economic significance of conference activity can be measured in a transparent and replicable fashion, enabling reliable comparison between MICE and other economic activities, and between MICE activities in different places. Secondly, to assess whether such analysis is cost effective and useful given prevailing policy contexts (and at different spatial scales). This paper provides a third, related contribution in that it evidences a way in which established satellite accounting methodologies, specifically tourism satellite accounts (TSAs), can be adapted and extended to provide information on the economic scale of other formerly "hidden" economic activities (Jones, Li, 2015).

In the chapter above few details about regions where mentioned. But it is worth to remember that events mean places. Humans usually meet in conference venues, congress centers and unique locales. "In common with tourism in general, MICE happens not in countries but in places - largely in cities - and it is at this spatial scale that many relevant policy decisions arise. We therefore here comment briefly on the difficulties involved in estimating economic significance of MICE at subnational scale" (Jones, Li, 2015).

\section{Social and cultural value of business events}

Social and cultural value of business events are often discussed by people dealing with the fields of managing events, marketing and communication. Available publications focus largely on the practical approach; meanwhile, so far, there have been no studies ordering the activities and definitions connected with this field. Event management has been developing dynamically in the USA, Asia, Australia and Pacific as well as in Europe. The synergy of activities connected with the creative industry, marketing and logistics has led to the emergence of a new sector which frequently influences decisions regarding further operation of enterprises or international holdings. As a result, statistics are proving that it pays off for towns to solicit the organization of conferences or 
congresses. What is more, one might even venture a thesis that despite the effects of the economic crisis that are still being experienced and the general availability of technological solutions which could replace the traditional mode of conducting discussions and exchanging views, the number of these types of meetings is not about to decline. The reason for this is simple. In the most general terms, the goal of the meetings is to enable transferring and accumulating knowledge, sharing opinions, discussing problems, understanding respective needs, learning about new possibilities, and reaching conclusions which might result in changing the reality. The list of partial goals of organizing conferences and congresses may be very long. Importantly, in the long-term, the assumption for organizing such meetings is to strive for change and progress or, if specific conclusions are hard to achieve, at least to start a general debate on a given topic.

However, these days it is crucial to focus on content rather than the logistic aspects, especially when we are talking about associations meetings. Being involved in choosing the next destination of international congress, scientific committees more often look for strong science connections and university background. They want to make an impact which is rather linked to social and human aspect than to economy. More important in this case is legacy, something which will last longer than money.

Naturally, the so-called conference planners responsible for organising events are not usually responsible for their content. Instead, they are focusing on organisational and logistic issues. Meanwhile, some practitioners and market researchers venture theories that the form and content of a meeting should be combined through the competences of a professional meeting architect (Vanneste, 2009).

XXI century is the time of events. We need to meet, we like meetings and we cannot exist without them. They change life, attitude and help create a better future.

Organizations and destinations bid aggressively to attract events for their tourism and imagemaking value, while other events are created to fill gaps in ever-larger and more ambitious portfolios of events. The consumers of event have numerous choices, and indeed they expect their communities to offer a wide variety. Events of all kinds have been legitimatized as essential ingredients in modern life (Sharples, Crowther, May, Orefice, 2014).

To measure the success of business events we need to focus on a few different aspects. Economic impact is of course one of them. The world is money driven but we need to remember about social aspects too. In addition, it is really difficult to measure all events using the same methodology, aspects etc. Mega sport events are an enormous challenge in comparison to small corporate sales training. However, it is possible to select measures which could fit particular projects. 
Tahle 1. Typical measures for meetings and events

\begin{tabular}{|c|c|}
\hline Project & Key Impact Measurements \\
\hline Anti-social behavior conferences & Complaints, turnover, absenteeism, productivity, employee satisfaction \\
\hline Association meetings & Productivity, sales, quality, time, costs, customer service, turnover, absenteeism, job satisfaction \\
\hline Business coaching conferences & $\begin{array}{l}\text { Productivity/ output, quality, time savings, efficiency, costs, employees satisfaction, customer } \\
\text { satisfaction }\end{array}$ \\
\hline Career-Focused Meetings & Enrollments, promotions, recruiting expenses, turnover, job satisfaction \\
\hline Communications meetings & Errors, stress, conflicts, Productivity, job satisfaction \\
\hline Compliance meetings & Penalties/fines, charges, settlements, losses \\
\hline Dealer meetings & Sales, market share, cost of sales, quality efficiency, customer loyalty \\
\hline Diversity meetings & Turnover, absenteeism, Complaints, charges, settlements, losses \\
\hline Employee retention meetings & Turnover, engagement, job satisfaction, promotions \\
\hline Engineering/technical conferences & $\begin{array}{l}\text { Productivity/output, quality, waste, downtime, cycle time, process time, costs, customer satisfaction, } \\
\text { job satisfaction }\end{array}$ \\
\hline Executive conferences & $\begin{array}{l}\text { Productivity, sales, quality, time, costs, customer satisfaction, market share, turnover, } \\
\text { absenteeism, job satisfaction }\end{array}$ \\
\hline Golfing events & Sales, market share, customer loyalty, new accounts, upselling \\
\hline Indoctrination/ orientation meetings & Early turnover, training time, Productivity, performance \\
\hline Labor-management conferences & Work stoppages, grievance, absenteeism, job satisfaction \\
\hline Leadership retreats & Productivity/output, quality, efficiency, cost/time savings, employee satisfaction, engagement \\
\hline Management conferences & Productivity, sales, quality, time, costs, customer service, turnover, absenteeism, job satisfaction \\
\hline Medical meetings & Medical costs, quality, compliance, efficiency, patient satisfaction \\
\hline Personal productivity meetings & Time savings, productivity, stress reduction, job satisfaction \\
\hline Project management conferences & Time savings, quality improvement, budgets \\
\hline Quality meetings & Defects, rework, response times, cycle times, costs \\
\hline Safety meetings & Accident frequency rates, accident severity rates, first aid treatments \\
\hline Sales meetings & Sales, market share, customer loyalty, new accounts, brand awareness \\
\hline Supervisor/team leader meetings & Productivity, sales, quality, time, costs, customer service, turnover, absenteeism, job satisfaction \\
\hline Team-building sessions & Productivity, sales, quality, time, costs, customer service, turnover, absenteeism, job satisfaction \\
\hline Wellness/fitness meetings & Stress, turnover, medical costs, accidents, absenteeism \\
\hline
\end{tabular}

Source: Phillips, Myhill, McDonough (2010).

Measuring the success of business events is one aspect but showing the channels and how big the influence can be is another story which should be mentioned as well.

Cooper et al. (1993) refer "cascading" effect of tourist expenditure, with the benefits of tourist spending being felt in hotels, restaurants, taxi firms and shops, and then permeating through the rest of economy. From this total direct impact, however, must be subtracted the cost of "imports necessary to supply those front-line goods and services...for example, hotels purchase the services of builders, accountants, banks, food and beverage suppliers, and many others". These suppliers will, in turn, purchase goods and services from other suppliers, generating further rounds of economic activity, known as the indirect effect (Rogers, 2003).

Other aspects, if we are talking about social impact, are environment and local communities. Eco-friendly meetings, corporate social responsibility or mega trend among venues to become self-sustaining are these days the basic elements of the bidding process in every part of the world. 
There are also issues concerning $\mathrm{CO}_{2}$ emissions by venues and the levels of waste generated by exhibitions/ expositions (which are often staged alongside a conference). A number of tentative steps are being taken to address these environmental factors (such as the development of quieter aircraft to reduce noise pollution, the work of the International Hotels Environment Initiative, the adoption of waste management and recycling strategies, more energy-efficient systems in conference venues, the use of email and electronic communications to reduce paper waste) but it is clear that much more needs to be done before the industry can claim genuine "green" credentials (Rogers, 2003).

Last but not least it is worth mentioning human beings as the most important piece of business events world or meetings industry. It is not really important where attendees come from and where do they meet. Always when magic happens people are changing the world. However, it is proven that meetings can also change the behaviors of local economies, communities and people in person.

Social disruption to the local community is inevitably caused when a major convention comes to town, especially where there is a need for high levels of security. This can mean that the area surrounding the convention center is cordoned off during the convention and often for some more days in advance, making it a "no-go area" for local residents, and reducing trade for shops and other businesses in the vicinity. Similarly, restaurants may be full of delegates eating out, traffic may be congested and public transport overloaded. While most local communities now recognize that such inconveniences are a price worth paying because of the wider economic benefits, there is often still a minority of residents who voice criticisms (Rogers, 2003).

To sum up, it is really important when speaking about business events to mention all the aspects of economic and social attitudes. Naturally, life events are active, energetic and fast living structures which could be driven by different mentors. One of the examples is described below and it shows the comprehensive collaboration of suppliers, planner, government, non-governmental organization linked to meetings industry and regional authorities.

\section{Case study - Poland Meetings Impact}

The goal of the study conducted as part of The Economic Impact of Poland's Meetings Industry Poland Meetings Impact 2015 project was to quantify the economic importance of meetings and events (i.a. social, economic, business) staged in Poland and show their economic contribution. This objective inspired research questions inquiring about the structure of the expenditures of meeting and event participants, the Gross Domestic Product generated thanks to Poland's meetings industry and the number of jobs created to perform services for meetings and events in Poland. In other words, the substantive scope encompassed economic aspects connected with the industry's impact on the national economy in reference to fundamental reference points, i.e. value added, GDP and employment. 


\section{POLAND MEETINGS IMPACT 2015}

THE ECONOMIC IMPACT OF POLAND'S MEETINGS INDUSTRY

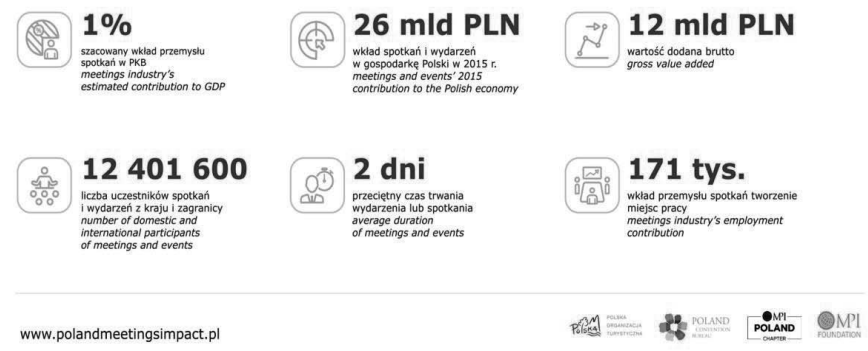

Figure 2. Poland meetings impact 2015

Source: MPI Poland Chapter (2017).

The project's three-stage analysis examined three groups of stakeholders: participants, organizers of meetings and events (seven categories) and venue administrators (twelve categories). The goal was achieved thanks to the collected data and an econometric model based on the data of the Central Statistical Office of Poland, built specifically to determine the meetings industry's impact on national economy. The research estimated the meetings industry's contribution to GDP at the level of 1\%. In 2015 meetings and events generated PLN 25,911,301,000 for Poland's economy and PLN 11,960,058,000 of gross value added. 12,401,600 domestic and international participants attended the meetings and events, which on average lasted two days. The meetings industry's employment contribution amounted to 171,000 .

The Wplyw ekonomiczny przemystu spotkań na gospodarkę Polski-Poland Meetings Impact 2015 report was compiled by a team of researchers and industry experts working under the auspices of Meeting Professionals International Poland Chapter and Poland Convention Bureau POT, in cooperation with regional convention bureaux from Poland, venues hosting meetings and events, as well as meeting organizers. Poland's very first publication of this kind also covered pioneering research on the meetings industry's impact on the economies of select countries, presented and sorted out terminology issues, as well as profiled Poland's meetings sector.

\section{Conclusions}

Discussion about economic impact and its significant role is not only important but also very popular among practitioners. To build new convention center, establish convention bureau or bring international associations to the destination, a huge power and collaboration is needed. The tourism industry not only proved its role but also, thanks to Tourism Satellite Accounting, showed the value and brought the political support among its activities. 
Given the above discussion, it is plain that a transparent, replicable approach to MICE economic impact estimation, embedded in systems of national accounts (SNA), is a laudable and policy-relevant objective. The development of Tourism Satellite Accounting methodologies by UNWTO and partners, particularly since the Nice conference of 1991 has provided an ideal context within which to understand the economic significance of MICE (Jones, Li, 2015).

The measures that we have mentioned above are surely the tools to show what business can bring to destination. However, it is still a huge discussion about the future of mega events, sport events and association market.

The good news is that most meetings and events are driving business measures. The measures are based on what is being changed in the various business units, divisions, regions, and individual workplaces. These are the measures that matter to senior executives. The difficulty often comes in ensuring that the connection to the meeting exists. This is accomplished through a variety of techniques which isolated the effects of the meeting on the particular business measures and will be discussed later (Phillips, Myhill, McDonough, 2010).

Finally, we need to mention that the business events impact from economic and social aspect is more and more important for decision makers globally, including scientific committees, politicians and regional governments. A link between human beings and events is and will be stronger based on impact supported by social aspects and money drivers.

\section{References}

Cooper, C., Fletcher, J., Gilbert, D., Fyall, A., Wanhill, S. (1993). Tourism: principles and practice, Harlow: Prentice Hall Financial Times.

Celuch, K. (2010a). In: J. Siemiński, Kształtowanie następnego pokolenia profesjonalistów dla turystyki biznesowej. Warsaw: Wydawnictwo Uczelni Vistula.

Celuch, K. (2010b). Managing content, product and motivation in meetings and events industry. Warsaw: Vistula University.

Davidson, R., Cope, B. (2001). Turystyka biznesowa: Konferencje, podróże motywacyjne, wystawy, turystyka korporacyjna. Warsaw: Wydawnictwo Wyższej Szkoły Ekonomiczno-Informatycznej w Warszawie.

Events Industry Council (2015). APEX Industry Glossary, The glossary of the meetings, conventions and exhibitions industry. Alexandria, VA, USA.

GUS (2002). Rachunki narodowe wedlug sektorów i podsektorów instytucjonalnych w latach 1995-2000. Warsaw: Central Statistical Institution.

ICCA (2017). Statistics Report the International Association Meetings Market. Amsterdam: International Congress and Convention Association.

Jones, C., Li, S. (2015). The economic importance of meetings and conferences: A satellite account approach. Annals of Tourism Research, 52, 117-133.

MPI Poland Chapter (2017).

Phillips, J., Myhill, M., McDonough, J. (2010). Proving the value of meetings and events. How and why to measure ROI. Birmingham, Ala: ROI Institute.

Rogers, T. (2003). Conferences and Conventions. A global industry. Oxford: Elsevier/Butterworth-Heinemann.

Sharples, L., Crowther, P., May, D., Orefice, C. (2014). Strategic Event Creation. Oxford: Goodfellow Publishers Limited. Vanneste, M. (2009). Meeting Architecture, a manifesto. Turnhout: Meeting Support Institute.

UNWTO (2006). Measuring the Economic Importance of the Meetings Industry. Developing a Tourism Satellite Account Extension. Madrid. 


\section{SPOŁECZNA, KULTUROWA I EKONOMICZNA WARTOŚĆ WYDARZEŃ \\ BIZNESOWYCH -PROJEKTOWANIE DOŚWIADCZEŃ OPARTYCH \\ O MERYTORYKĘ I KREATYWNOŚĆ}

SŁOWA KLUCZOWE

STRESZCZENIE spotkania, kultura, wydarzenia, organizacje, kreacja, kongresy, konferencje

Aby zachęcić do intensywniejszych dyskusji między różnymi dziedzinami interdyscyplinarnymi i zsyntetyzować różnorodność wydarzeń biznesowych w spójne ramy, które zwiększają zrozumienie w nieprzewidywalnym świecie spotkań stowarzyszeń i wydarzeń korporacyjnych, musimy skoncentrować się na pieniądzach. Głównym celem napisania tego artykułu było opracowanie wartości wydarzeń w różnych perspektywach. W szczególności wiąże się to z drugą najważniejszą kwestią po interakcjach z ludźmi, czyli z wpływem wydarzeń na biznes. Przemysł spotkań wpływa na rozwój gospodarczy krajów; pomaga również zwiększyć wskaźnik zatrudnienia w regionach, w których jak dotąd rozwój szeroko rozumianej turystyki okazał się problematyczny. Zaleca się nie tylko rozważenie jego możliwości, ale także zintensyfikowanie działań związanych z jego promocją, zarządzaniem i organizacją. Zarządzanie przemysłem spotkań jako nowe i innowacyjne zjawisko ujawnia różne luki w jego rozwoju systemowym. 